\title{
Tingkat Penerangan dan Jarak Membaca Meningkatkan Kejadian Rabun Jauh (Miopia) pada Remaja
}

\author{
Lighting Levels and Reading Distance Increase Occurrence \\ Nearsightedness (Myopia) in Adolescents \\ Khusni Karim ${ }^{1, ~}{ }^{凶}$, Ihsan Taufiq ${ }^{1}$ \\ 1Jurusan Keperawatan, Politeknik Kesehatan Tanjung Karang, Indonesia \\ $\bowtie$ Corresponding author: Ihsantaufiq1112@gmail.com
}

Kata kunci:
Rabun jauh (miopia),
tingkat penerangan,
jarak baca.

Keyword:

Myopia,

level of lighting,

distance read.

\begin{abstract}
Abstrak
Latar belakang: Data WHO pada tahun 2004 menunjukkan angka kejadian $10 \%$ dari 66 juta anak usia sekolah menderita kelainan refraksi, yaitu miopia. Puncak terjadinya miopia adalah pada usia remaja yaitu pada tingkat SMA (1618 Tahun). Pada tahun 2012 berjumlah 226 kasus yang terdiri dari 40 kasus lama dan 186 kasus baru. Tujuan: penelitian ini bertujuan untuk mengetahui hubungan tingkat penerangan dengan jarak membaca dengan kejadian miopia di SMA Negeri 03 Kotabumi Kecamatan Kotabumi Selatan. Desain penelitian korelasi analitik dengan metode cross sectional. Metode: Populasi dalam penelitian ini adalah seluruh siswa di SMA Negeri 03 Kotabumi Kecamatan Kotabumi Selatan dengan jumlah sampel 85 orang. Data diambil dengan teknik quota sampling dengan cara accidental sampling. Variabel yang dianalisis adalah tingkat penerangan dan jarak membaca, serta kejadian miopia dengan analisis bivariat menggunakan uji chi square. Hasil: hasil penelitian menunjukkan bahwa 45,9\% menderita miopia dan54,1\% tidak miopia. Hasil uji chi square menunjukkan ada hubungan antara tingkat penerangan dengan kejadian miopia $(p=0,010 ; \alpha=0,05)$ dan ada hubungan antara jarak membaca dengan kejadian miopia ( $p=0,000 ; \alpha=0,05$ ). Simpulan: Faktor tingkat penerangan dan jarak membaca berhubungan dengan peningkatan dengan kejadian miopia pada remaja. Perlu upaya penurunan miopi dengan membaca pada tempat yang terang dan jarak baca yang ideal $(>30 \mathrm{~cm})$.
\end{abstract}

\begin{abstract}
Background: WHO data in 2004 showed an incidence of $10 \%$ of 66 million school-age children suffering from refractive disorders, namely myopia. The peak of myopia is in adolescence at the high school level (16-18 years). In 2012 there were 226 cases consisting of 40 old cases and 186 new cases. Purpose: this study aims to determine the relationship of the level of illumination with reading distance with the incidence of myopia in SMA Negeri 03 Kotabumi, Kotabumi Selatan District. Methods: Research design analytic correlation with cross sectional method. The population in this study were all students in SMA Negeri 03 Kotabumi, Kotabumi Selatan District with a total sample of 85 people. Data is taken by quota sampling technique by accidental sampling. The variables analyzed were the level of illumination and reading distance, and the incidence of myopia by bivariate analysis using the chi square test. Results: The results showed that $45.9 \%$ had myopia and $54.1 \%$ had no myopia. Chi square test results show there is a relationship between the level of illumination with the incidence of myopia ( $p=0.010 ; \alpha=0.05)$ and there is a relationship between reading distance and the incidence of myopia $(p=0,000 ; \alpha=0.05)$. Conclusion: Factors of light level and reading distance are associated with an increase in the incidence of myopia in adolescents. Efforts to reduce myopia by reading in a bright place and an ideal reading distance (> $30 \mathrm{~cm})$.
\end{abstract}

Copyright $(2017$ Jurnal Kesehatan Metro Sai Wawai. All rights reserved. 


\section{Pendahuluan}

Miopia adalah suatu keadaan mata yang mempunyai kekuatan pembiasan sinar yang berlebihan sehingga sinar sejajar yang datang dibiaskan di depan retina (bintik kuning). Pada miopia, titik fokus sistem optik media penglihatan terletak di depan makula lutea. Hal ini dapat disebabkan sistem optik (pembiasan) terlalu kuat, miopia refraktif atau bola mata terlalu panjang. Miopia adalah suatu bentuk kelainan refraksi dimana sinar-sinar sejajar yang datang dari jarak tidak terhingga oleh mata dalam keadaan tidak berakomodasi dibiaskan pada satu titik di depan retina (Ilyas, 2012).

Miopia dan miopia tinggi diperkirakan mempengaruhi 27\% (1893 juta) dan 2,8\% (170 juta) dari populasi dunia, masing-masing, pada tahun 2010. Menurut penelitian yang diterbitkan, prevalensi miopia tertinggi di Asia Timur, di mana China, Jepang, Republik Korea dan Singapura memiliki prevalensi sekitar 50\%, dan lebih rendah di Australia, Eropa dan Amerika Utara dan Selatan. Proyeksi sementara berdasarkan pada data prevalensi ini dan angka populasi PBB yang sesuai, dan akuntansi untuk efek usia dan waktu, tunjukkan bahwa miopia dan miopia tinggi akan mempengaruhi masingmasing 52\% (4949 juta) dan 10,0\% (925 juta) populasi dunia pada tahun 2050 (WHO, 2015).

Di Indonesia, dari hasil Riskesdas tahun 2013 menunjukkan prevalensi pemakaian kaca mata atau lensa kontak di Indonesia menurut tingkat pendidikan yaitu: 2,3\% tidak sekolah, 2,2\% tidak tamat SD, 3,6\% tamat SD, 4,0\% tamat SMP, 7,0\% tamat SMA, 15,6\% tamat Perguruan Tinggi. Bahkan, penurunan ketajaman penglihatan > 6 tahun sebesar 5,1\% (Kemenkes RI, 2013). Di provinsi Lampung penurunan ketajaman penglihatan pada usia $\geq 6$ tahun sebesar 3,7\% (Depkes, 2008). Sedangkan, tahun 2013 di provinsi Lampung penurunan ketajaman penglihatan pada usia $\geq 6$ tahun sedikit meningkat menjadi 3,8\% (Kemenkes RI, 2013). Laporan Dinas Kesehatan kabupaten Lampung Utara dalam Laporan Bulanan data kesakitan (LB.1) dalam dua tahun 2011 dan 2012. Jumlah masyarakat Lampung Utara yang menderita miopia yaitu tahun 2011 berjumlah 50 kasus yang terdiri dari 24 kasus lama dan 28 Kasus Baru. Pada tahun 2012 berjumlah 226 Kasus yang terdiri dari 40 Kasus Lama dan 186 Kasus Baru. Di kabupaten Lampung Utara prevalensi kelainan refraksi (miopi) belum diketahui, hal ini terjadi karena terkendala (tenaga, sarana dan dana), akibatnya penderita kelainan refraksi anak sekolah belum diketahui estimasi jumlah dan penyebabnya (Dinkes Lampung Utara, 2013).

Masalah miopia pada masa remaja terutama remaja SMA memiliki beberapa dampak negatif diantaranya yaitu penurunan prestasi belajar anak. Penelitian tentang hubungan kelainan refraksi dengan prestasi belajar anak di SMP Kristen Eben Haezar 2 Manado menunjukkan penderita kelainan refraksi ( $\mathrm{p}=0,010$ ) berhubungan secara signifikan dengan prestasi belajar (Rumondor \& Rares, 2014). Faktor resiko terjadinya miopia, yaitu yang berhubungan dengan faktor herediter atau keturunan dan lingkungan. Terdapat dua faktor utama yang menjadi resiko terjadinya miopia, yaitu: faktor herediter atau keturunan, faktor lingkungan, meliputi: membaca atau kerja dekat, pendidikan, tingkat penerangan, intelegensi dan status sosio-ekonomi, malnutrisi, tinggi badan dan kepribadian (Ilyas, 2012).

Gangguan penerangan dapat menimbulkan gangguan akomodasi mata, kontraksi otot siliaris secara terus-menerus akan menimbulkan gangguan refraksi mata yaitu miopia. Kebiasaan buruk yang dapat mengganggu kesehatan mata kita seperti membaca sambil tidur-tiduran, membaca di tempat yang gelap, membaca di bawah sinar matahari langsung yang silau, menatap sumber cahaya terang langsung, dan lain sebagainya. Tingkat penerangan juga dianggap sebagai faktor pencetus yang mempengaruhi timbulnya miopia pada faktor lingkungan. Gangguan penerangan dapat menimbulkan gangguan akomodasi mata, kontraksi otot siliar secara terus-menerus akan menimbulkan kelelahan mata dan pada akhirnya dapat menimbulkan gangguan refraksi mata, yaitu miopia. Aktivitas melihat dekat jangka panjang menyebabkan miopia melalui efek fisik langsung akibat akomodasi terus-menerus sehingga tonus otot siliaris menjadi tinggi dan lensa menjadi cembung, namun berdasarkan teori terbaru, aktivitas 
melihat dekat yang lama menyebabkan miopia melalui terbentuknya bayangan buram di retina (retinal blur) yang terjadi selama fokus dekat (Fredrick, 2002).

Hasil penelitian prevalensi kelainan tajam penglihatan tahun 2009 di Fakultas Kedokteran Universitas Indonesia menunjukkan responden yang mempunyai kebiasaan membaca dalam jarak dekat dan lama hanya sebesar 4,9\%. Berdasarkan uji kemaknaan tidak terdapat hubungan yang bermakna antara kebiasaan membaca dalam jarak dekat dan lama dengan kelainan tajam penglihatan $(p=0,663)$ (Fachrian, D, 2005). Sedangkan, Hasil penelitian menunjukkan faktor jarak membaca meningkatkan kejadian miopia pada remaja. Penelitian sebelumnya yang dilakukan terhadap sampel 92 siswa SMA N 2 Temanggung memperoleh hasil terdapat hubungan antara jarak baca. Remaja dengan kebiasaan membaca jarak dekat meningkatkan kejadian miopia 13 kali dibandingkan remaja yang membaca dengan jarak optimal atau $>30 \mathrm{~cm}$ (ORadjusted $=13,164)$ (Sofiani \& Puspita, 2016).

Perbandingan tiga Sekolah Menengah Atas (SMA) Negeri di kecamatan Kotabumi Selatan, yaitu: SMA Negeri 01 Kotabumi, SMA Negeri 03 Kotabumi, dan SMA Negeri 04 Kotabumi. Di SMA Negeri 03 Kotabumi dari jumlah 864 siswa-siswi terdapat 31 orang menderita miopi. Di SMA Negeri 04 Kotabumi dari jumlah 751 siswa-siswi terdapat 19 orang menderita miopi. Di SMA Negeri 1 Kotabumi dari jumlah siswa 782 siswa-siswi terdapat 23 orang menderita miopi.

Berdasarkan maslah di atas sudah banyak penelitian yang telah meneliti faktor-faktor yang berhubungan dengan miopia, seperti jenis kelamin, keturunan, dan kebiasaan membaca di lokasi penelitian yang berbeda, akan tetapi peneliti lebih tertarik untuk meneliti tentang faktor tingkat penerangan dan jarak membaca dengan miopia. Oleh karena itu, penelitian ini bertujuan untuk mengidentifikasi hubungan tingkat penerangan dan jarak membaca dengan kejadian miopia pada remaja.

\section{Metode Penelitian}

Penelitian ini menggunakan rancangan cross sectional. Populasi pada penelitian ini adalah seluruh siswa di SMA Negeri 03 Kotabumi Kecamatan Kotabumi Selatan yaitu 576 orang, ditetapkan jumlah sampel 85 siswa dengan menggunakan teknik sampling quota dan teknik accidental sampling dimana memilih sampel sesuai dengan tujuan penelitian.

Variabel pada penelitan ini adalah kejadian miopia sebagai variabel dependent serta jarak membaca dan tingkat penerangan sebagai varibel independent. Kejadian miopia diperoleh dari pemeriksaan ketajaman penglihatan menggunakan snellen card dengan hasil penelitian dikategorikan rabun dekat (miopia) dan tidak. Sedangkan jarak membaca dan tingkat penerangan diperoleh menggunakan kuesioner, data hasil penelitian dikategorikan jarak baca $<30$ (terlalu dekat) $\mathrm{cm}$ dan $\geq 30$ $\mathrm{cm}$. Data dikumpulkan dengan wawancara menggunakan kuesione yang konstruksi sesuai teori terkini.

Pengolahan data dilakukan dengan tahapan analisis univariat dan bivariat. Analisis univariat berbentuk distribusi frekuensi. Sedangkan, analisis bivariat menggunakan chi Square $\left(\chi^{2}\right)$ dengan $\alpha=$ 0,05 .

\section{Hasil Penelitian}

\section{Analisa Univariat}

Analisis univariat menampilkan distribusi frekuensi dari masing-masing variabel, yaitu variabel dependent (kejadian miopia) dan variabel independent (tingkat penerangan dan jarak membaca). Tabel 1 menunjukkan distribusi frekuensi kejadian miopia pada siswa di SMA Negeri 03 Kotabumi Kecamatan Kotabumi Selatan yaitu diketahui siswa di SMA Negeri 03 Kotabumi mengalami miopia sejumlah 45,88\%. Tingkat penerangan pada siswa-siswi di SMA Negeri 03 Kotabumi Kecamatan Kotabumi Selatan yaitu penerangan yang tidak ideal sebesar 30,6\% yang seharusnya penggunaan penerangan untuk kegiatan membaca harus menggunakan penerangan yang ideal. Jarak 
membaca buku atau bahan bacaan pada siswa di SMA Negeri 03 Kotabumi kecamatan Kotabumi Selatan sejumlah 44,70\% siswa-siswi membaca buku atau bahan bacaan pada jarak < $30 \mathrm{~cm}$ dan sejumlah 55,30\% siswa-siswi membaca buku atau bahan bacaan pada jarak $\geq 30 \mathrm{~cm}$ yang idealnya untuk kegiatan membaca jarak mata dengan bahan bacaan harus $\geq 30 \mathrm{~cm}$ untuk mengurangi kelelahan mata saat membaca.

\section{Analisa Bivariat}

Analisa bivariat untuk mengetahui hubungan antara variabel dependent (kejadian miopia) dan variabel independent (tingkat penerangan dan jarak baca) diperoleh data sebagaimana ditunjukkan pada tabel 2. Tabel 2 meruapakan hasil analisis hubungan antara tingkat penerangan dengan kejadian miopia didapatkan nilai $p=0,010<\alpha(0,05)$, artinya terdapat hubungan antara tingkat penerangan dengan kejadian miopia, begitu pula hubungan antara jarak membaca dengan kejadian miopia didapatkan nilai $p=0,000<\alpha(0,05)$, artinya terdapat hubungan antara jarak membaca dengan kejadian miopia.

Tabel 1

Distibusi Frekuensi Kejadian Miopia, Tingkat Penerangan, dan Jarak Membaca

\begin{tabular}{llcc}
\hline \multicolumn{1}{c}{ Variabel } & \multicolumn{1}{c}{ Kategori } & Frekuensi $(\mathbf{n = 8 5})$ & Presentase $(\boldsymbol{\%})$ \\
\hline Pemeriksaan Visus & Miopi & 39 & 45,9 \\
& Tidak Miopi & 46 & 54,1 \\
Tingkat Penerangan: & Tidak Ideal & 26 & 30,6 \\
& Ideal & 59 & 69,4 \\
Jarak Membaca: & $<30 \mathrm{~cm}$ & 38 & 44,7 \\
& $\geq 30 \mathrm{~cm}$ & 47 & 55,3 \\
\hline
\end{tabular}

Tabel 2

Hubungan antara Tingkat Penerangan dan Jarak Membaca dengan Kejadian Miopia

\begin{tabular}{lcccccccc}
\hline \multirow{2}{*}{ Variabel } & \multicolumn{4}{c}{ Pemeriksaan Visus } & & \multicolumn{2}{c}{ Jumlah } & \multirow{2}{*}{$\boldsymbol{p}$ value } \\
\cline { 2 - 5 } & \multicolumn{2}{c}{ Tidak Miopia } & \multicolumn{2}{c}{ Miopia } & & & \\
\hline Tingkat Penerangan & $\mathrm{n}$ & $\%$ & $\mathrm{n}$ & $\%$ & $\mathrm{~N}$ & $\%$ & 0,010 \\
$\quad$ Ideal & 26 & 44,1 & 33 & 55,9 & 59 & 100 & \\
$\quad$ Tidak Ideal & 20 & 76,9 & 6 & 23,1 & 26 & 100 & \\
$\quad$ Total & 46 & 54,1 & 39 & 45,9 & 85 & 100 & \\
Jarak Membaca & & & & & & & \\
$\quad<30 \mathrm{~cm}$ & 7 & 18,4 & 31 & 81,6 & 38 & 100 & $\left.0,000^{*}\right)$ \\
$\geq 30 \mathrm{~cm}$ & 39 & 83,0 & 8 & 17 & 47 & 100 & \\
Total & 46 & 54,1 & 39 & 45,9 & 85 & 100 & \\
\hline
\end{tabular}

\section{Pembahasan}

\section{Kejadian Miopia}

Miopia adalah mata dengan daya lensa positif yang lebih kuat sehingga sinar yang sejajar atau datang dari tak terhingga difokuskan di depan retina. Kejadian miopia pada remaja penelitian ini sejumlah 45,88\% dan tergolong tinggi jika dibandingkan dengan beberapa negara di dunia. Miopia dan miopia tinggi diperkirakan mempengaruhi 27\% (1893 juta) dan 2,8\% (170 juta) dari populasi dunia, masing-masing, pada tahun 2010. Menurut penelitian yang diterbitkan, prevalensi miopia tertinggi di Asia Timur, di mana China, Jepang, Republik Korea dan Singapura memiliki prevalensi sekitar 50\%, dan lebih rendah di Australia, Eropa dan Amerika Utara dan Selatan. Proyeksi sementara berdasarkan pada data prevalensi ini dan angka populasi PBB yang sesuai, dan akuntansi untuk efek usia dan waktu, tunjukkan bahwa miopia dan miopia tinggi akan mempengaruhi masing-masing 52\% (4949 juta) dan 10,0\% (925 juta) populasi dunia pada tahun 2050 (WHO, 2015). 
Kejadian miopia perlu upaya untuk diturunkan sejak dini khususnya pada anak-anak sekolah termasuk remaja. Cara untuk mencegah terjadinya miopia dapat dilakukan dengan:

a. Biasakan anak duduk dengan posisi tegak sejak kecil.

b. Memegang alat tulis dengan benar.

c. Lakukan istirahat setiap 30 menit setelah melakukan kegiatan membaca atau menonton televisi.

d. Batasi jam untuk membaca.

e. Atur jarak membaca buku dengan tepat (kurang lebih 30 centimeter dari buku) dan gunakan penerangan yang cukup.

f. Membaca dengan posisi tidur atau tengkurap bukanlah kebiasaan yang baik (Curtin, 2000).

\section{Tingkat penerangan dan kejadian miopia}

Penelitian ini bertujuan untuk menganalisis hubungan tingkat penerangan dengan kejadian miopia pada remaja. Hasil penelitian menunjukkan distribusi frekuensi tingkat penerangan yang tidak ideal sebesar 30,6\% yang seharusnya penggunaan penerangan untuk kegiatan membaca harus menggunakan penerangan yang ideal. Faktor tingkat penerangan meningkatkan kejadian miopia pada remaja.

Tingkat penerangan merupakan sejumlah arus cahaya yang jatuh pada suatu permukaan seluas 1 (satu) meter persegi sejauh 1 (satu) meter dari sumber cahaya 1 (satu) lumen. Sinar yang salah arah dan pencahayaan yang sangat kuat menyebabkan kilauan pada objek. Kilauan ini dapat menimbulkan kerusakan mata. Penyebaran cahaya di dalam ruangan juga harus merata supaya mata tidak perlu lagi menyesuaikan terhadap berbagai kontras silau, sebab keanekaragaman kontras silau menyebabkan kelelahan mata. Kelelahan mata dapat menyebabkan iritasi, mata berair dan kelopak mata berwarna merah (konjungtivitis), penglihatan rangkap, sakit kepala, ketajaman penglihatan merosot, begitu pula kepekaan terhadap perbedaan (contrast sensitivity) dan kecepatan pandangan serta kekuatan menyesuaikan (accomodation) dan konvergensi menurun (Ilyas, 2012).

Tingkat penerangan dianggap sebagai faktor pencetus yang mempengaruhi timbulnya miopia pada faktor lingkungan. Berdasarkan sebuah penelitian yang diterbitkan dalam British Medical Journal diungkapkan bahwa membaca di bawah cahaya rendah tidak merusak mata, tapi menyebabkan ketegangan mata, sebaliknya gangguan penerangan dapat menimbulkan gangguan akomodasi mata, kontraksi otot siliar secara terus-menerus akan menimbulkan gangguan refraksi mata, yaitu miopia. (Fredrick, 2012).

Untuk menyelesaikan masalah penerangan yang tidak ideal, dalam praktiknya dibutuhkan penggunaan lampu yang memiliki daya $<10 \mathrm{watt} / \mathrm{m}^{2}$ untuk kegiatan membaca. Selain itu, diperlukan pula pemilihan warna ruangan baca untuk memaksimalkan penerangan di ruang baca, dan diperlukan pula penempatan posisi lampu yang tepat (Kurniasih, 2014). Hendaknya remaja, termasuk anak sekolah memperhatikan penerangan tempat membaca atau penerangan oleh lampu saat membaca, sehingga dapat mencegah atau meminimalkan terjadinya rabun dekat (miopi).

\section{Jarak baca dan dan kejadian miopia}

Penelitian ini bertujuan untuk mengetahui hubungan jarak membaca dengan kejadian miopia pada remaja. Diperoleh gambaran responden dari kebiasaan jarak membaca buku atau bahan bacaan < $30 \mathrm{~cm}$ sejumlah $44,70 \%$ orang. Hasil penelitian menunjukkan faktor jarak membaca meningkatkan kejadian miopia pada remaja. Penelitian sebelumnya yang dilakukan terhadap sampel 92 siswa SMA N 2 Temanggung memperoleh hasil terdapat hubungan antara jarak baca. Remaja dengan kebiasaan membaca jarak dekat meningkatkan kejadian miopia 13 kali dibandingkan remaja yang membaca dengan jarak optimal atau $>30 \mathrm{~cm}$ (ORadjusted $=13,164)$ (Sofiani \& Puspita, 2016). 
Jarak baca merupakan kegiatan visual yang dilakukan pada jarak dekat atau ketika seseorang harus fokus untuk melihat objek benda secara rinci. Pekerjaan jarak dekat seperti jarak membaca yang terlalu dekat $(<30 \mathrm{~cm})$ juga dapat meningkatkan terjadinya miopia pada anak. Kebiasaan membaca dalam jarak yang dekat dapat menyebabkan tonus otot siliaris menjadi tinggi, sehingga lensa menjadi cembung yang mengakibatkan bayangan objek jatuh di depan retina dan menimbulkan miopia. Berdasarkan teori terbaru, aktivitas melihat dekat yang lama menyebabkan miopia melalui terbentuknya bayangan buram di retina (retina blur) yang terjadi selama fokus dekat. Bayangan buram di retina ini memulai proses biokimia pada retina untuk menstimulasi perubahan biokimia dan struktural pada sklera dan koroid yang menyebabkan elongasi aksial. Untuk mengatasi masalah jarak membaca yang terlalu dekat dapat dilakukan dengan membiasakan membaca buku dengan jarak yang ideal dan menggunakan waktu yang tidak terlalu lama. Beberapa penelitian melaporkan bahwa usaha untuk melatih jauh atau melihat jauh dan dekat secara bergantian dapat mencegah terjadinya miopia (Fredrick, 2012). Hendaknya dicegah sejak dini terjadinya rabun dekat (miopi) pada anak sekolah maupun remaja dengan memperhatikan jarak baca minimal $30 \mathrm{~cm}$.

\section{Simpulan dan saran}

Penelitian memperoleh kesimpulan bahwa tingkat penerangan dan jarak membaca meningkatkan kejadian miopia pada responden. Pemeliharaan kesehatan mata, hendaknya dilakukan khususnya pada remaja diantaranya dengan menjaga penerangan cahaya yang optimum dan menjaga jarak membaca dengan sumber bacaan minimal $30 \mathrm{~cm}$, sehingga dapat mencegah kejadian rabut dekat (miopia).

\section{Referensi}

Curtin, B. J. (2000). The myopias: basic science and clinical management. Philadelphia: J.B Lippincott.

Dinkes Lampung Utara. (2013). Profil kesehatan Lampung Utara 2012. Kota Bumi: Dinkes Lampung Utara.

Elyas, S. (2012). Ilmu penyakit mata (4 ed.). Jakarta: Penerbit FKUI.

Fachrian, D. (2015). Prevalensi kelainan tajam penglihatan pada sekolah dasar. Jakarta: Penerbit FKUI.

Fredrick. (2012). British medical journal. Inggris: PMC.

Ilyas, S. (2000). Masalah kesehatan mata. Jakarta: Penerbit FKUI.

Ilyas, S. (2012). Ilmu penyakit mata. Edisi ke-4. Jakarta: FKUI. Jakarta: Penerbit FKUI.

Depkes RI. (2008). Riset kesehatan dasar tahun 2007. Jakarta: Depkes RI.

Kemenkes RI. (2013). Riset kesehatan dasar tahun 2013. Jakarta: Kemenkes RI.

Kurniasih, S. (2014). Optimasi sistem pencahayaan pada ruang kelas Universitas Budi Luhur. Retrieved April 14, 2014, from http://riset.budiluhur.ac.id/wp-content/uploads/2014/11/050107-021033-SKurniasih.pdf 11 Juni 2014

Rumondor, N. E., \& Rares, L. M. (2014). Hubungan kelainan refraksi dengan prestasi belajar anak di SMP Kristen Eben Haezar 2 Manado. Jurnal E-Clinic. 2(1) 1-6. DOI: https://doi.org/10.35790/ecl.2.1.2014.3609.

Sofiani, A., \& Puspita, Y. S. (2016). Faktor-faktor yang mempengaruhi derajat miopia pada remaja (Studi dI SMA Negeri 2 Temanggung Kabupaten Temanggung). Unnes Journal of Public Health, 5(2), 176-185. doi:https://doi.org/10.15294/ujph.v5i2.1012

WHO. (2015). The impact of myopia and high myopia: report of the Joint World Health Organization-Brien Holden Vision Institute Global Scientific Meeting on Myopia PDF . Sydney: University of New South Wales, Sydney, Australia, 16-18 March 2015. 